\title{
ANALISIS PRODUKSI TEMBAKAU RAJANGAN TIPE MAGELANGAN DALAM POLA KEMITRAAN CV. MERABU - PT. DJARUM KUDUS
}

\section{Analysis Production of Magelangan Type Cutting Tobacco in Merabu - Pt Djarum Kudus Partnership Pattern}

\author{
Eko Sumartono \\ Staff Pengajar Jurusan Sosial Ekonomi Pertanian Fakultas Pertanian \\ Universitas Bengkulu \\ Email: eko_vixion@unib.ac.id
}

\begin{abstract}
Purpose of this research is estimate level of input usage; production rate and level of productivity, and to determine factors influence produce of to produce and productivity at tobacco type rajangan public people type Magelangan. This research applies a descriptive method and multiple regresiion analysis. Result of research indicates that level of input usage, production rate and level of productivity, quality of tobacco type Magelangan has experienced a drastic degradation from the year 2005 to 2009. Hereinafter level of input usage experiences upsurge, although some inputs still experience a degradation. Land area, Ortheen/Roteen 75 SP, Year of 2006, Year of 2007 and Year of 2008 are significant factors affecting production while number of partnership member, NPK Fertil/Basal, Ortheen/Roteen 75 SP, Marcis, Year of 2006, Year of 2007 and Year of 2008 as well as year Of 2009 are important factors to affect productivity.
\end{abstract}

Keyword: Magelangan Tobacco type, production factors, production, productivity, partnership

\section{PENDAHULUAN}

Usaha perkebunan di Indonesia banyak dilakukan oleh para petani yang lebih dikenal dengan perkebunan rakyat. Kendala selama ini adalah kualitas dan kuantitas produktivitas perkebunan rakyat rendah jika dibandingkan dengan perusahaan besar yang memiliki modal, sumber daya manusia dan manajemen yang baik. Sebagaimana dipaparkan Situs Hijau-Media Pertanian Online Anda (2008), penyebab kurang optimalnya kegiatan agribisnis di Indonesia saat ini adalah pelaku usaha agribisnis di tingkat masyarakat banyak berada di sub sistem agribisnis hulu on-farm.

Salah satu kebijakan yang diimplementasikan dalam pengembangan sektor pertanian di Indonesia adalah pengembangan kemitraan petani dengan 
perusahaan. Program kemitraan yang terwujud dalam kerja sama antara pengelola dan petani tembakau selalu menjungjung tinggi nilai saling percaya dan usaha saling menguntungkan kedua belah pihak (Kuswanto, 2003)

Dalam pelaksanaannya, pola kemitraan ini juga didukung oleh pemerintah berdasarkan Keputusan Menteri Pertanian Nomor: 940/Kpts/OT.210/10/97 Tentang Pedoman Kemitraan Usaha Pertanian, tujuan kemitraan usaha pertanian untuk meningkatkan pendapatan, kesinambungan usaha, meningkatkan kualitas sumberdaya kelompok mitra, peningkatan skala usaha, dalam rangka menumbuhkan dan meningkatkan kemampuan usaha kelompok mitra yang mandiri.

Salah satu jenis komoditas perkebunan yang banyak dibudidaya masyarakat dan perkebunan besar adalah tanaman tembakau (Nicotina tabacum L.). Tanaman ini merupakan jenis tanaman perkebunan yang dimanfaatkan daunnya sebagai bahan pembuatan rokok yang terdiri dari rokok cerutu, rokok kretek, rokok putih, rokok pipa, dan sebagai kunyahan (Akehurst,1981). Menurut Balitas Malang (2000), pada tembakau rajangan kriteria seleksi umumnya diarahkan untuk mendapatkan produksi dan mutu tinggi. Karakterkarakter yang mengarah pada peningkatan produksi adalah jumlah dan ukuran daun.

Jumlah daun tembakau rajangan magelangan rata- rata \pm 20 - 28 lembar, panjang dan lebar bervariasi. Selain karakter kuantitatif, karakter kualitatif diperlukan sebagai penciri utama suatu varietas. Hal ini disebabkan karakter kualitatif sedikit sekali dipengaruhi oleh lingkungan dan mudah diwariskan (Allard, 1960).

Petani belum banyak yang terampil dalam berbudidaya tanaman tembakau karena petani umumnya memiliki pengalaman bertani secara turun temurun dengan sumber daya manusia yang masih rendah, baik ditinjau dari pendidikan, penguasaan teknologi, penguasaan pasar serta permodalan. Mengatasi permasalahan di atas pemerintah terus berupaya melakukan pembinaan dan bantuan kepada para petani serta menghimbau pihak swasta agar mau melakukan pembinaan terhadap petani baik menyangkut budidaya, produksi maupun pemasaran. Salah satu perusahaan pekebunan yang tertarik dalam melakukan kemitraan dengan petani tersebut adalah CV. MERABU, perusahaan yang bergerak di bidang pengelolaan komoditas tembakau rajangan rakyat dengan Tipe Magelangan.

Dalam pelaksanaan pola kemitraan tersebut CV. MERABU mengalami berbagai masalah, produktivitas tembakau petani mitra masih rendah, masih terdapat petani mitra yang tidak mampu mengembalikan kredit kepada perusahaan serta kurangnya minat bertani dari petani mitra. CV. MERABU menyediakan sarana produksi dan pembinaan usahatani tembakau rajangan rakyat, namun produktivitas petani mitra masih rendah. Rendahnya produktivitas tembakau petani mitra disebabkan penggunaan faktor-faktor 
produksi seperti bibit, pupuk, penggunaan pestisida, tenaga kerja dan lahan yang belum optimal.

Menurut Soekartawi (1994), Faktor produksi sering pula disebut dengan korbanan produksi, karena faktor produksi tersebut dikorbankan untuk menghasilkan produksi. Produksi (production) merujuk pada perubahan bentuk berbagi input atau sumber daya menjadi output berupa barang dan jasa, (Salvatore, 2005). Menurut Heady dan Dillon (1965) produksi adalah merupakan kombinasi berbagai faktor produksi misalnya bagaimana mengalokasikan dan bagaimana agar sumber daya itu tetap menghasilkan produksi.

Berdasarkan deskripsi pada latar belakang maka permasalahan yang dialami oleh CV. MERABU adalah penggunaan faktor-faktor produksi yang belum optimal oleh petani mitra, menyebabkan produksi tembakau belum sesuai dengan harapan. Tembakau rajangan rakyat memiliki produktivitas 1,4 1,8 Ton/Ha, sedangkan petani mitra baru menghasilkan $0,8-1,2$ ton/ha. Maka produksi yang rendah menyebabkan petani memiliki pendapatan yang rendah. Petani tentunya terlebih dahulu menggunakan pendapatan untuk memenuhi kebutuhan pokok terlebih dahulu.

Tujuan dari penelitian ini adalah mengetahui tingkat penggunaan input, tingkat produksi dan produktivitas, pengaruh faktor-faktor produksi terhadap produksi dan produktivitas pada jenis tembakau rajangan rakyat tipe Magelangan dan tipe Muntilanan pada pola kemitraan CV. MERABU.Hipotesis dalam penelitian ini yaitu diduga bahwa luas lahan, jumlah petani, benih, pupuk, dan beberapa pestisida berpengaruh terhadap produksi dan produktivitas tembakau rajangan rakyat tipe Magelangan pada CV. MERABU.

\section{METODE PENELITIAN}

Penelitian dilakukan di CV. MERABU dimana lokasi perusahaan di Kota Magelang Provinsi Jawa Tengah. Pemilihan lokasi berdasarkan pertimbangan bahwa perusahaan ini yang dipercaya PT. Djarum untuk mengelola tembakau diwilayah G. Merapi dan G. Merbabu yang bergerak di bidang Agribisnis, yaitu bidang Perkebunan Tembakau yang melaksanakan pola kemitraan dengan petani tembakau.

\section{Pendekatan Penelitian}

Metode dasar yang digunakan adalah metode deskriptif. Tujuan penelitian deskriptif adalah untuk membuat deskripsi, gambaran secara sistematis, aktual dan akurat mengenai fakta-fakta, sifat-sifat serta hubungan antara fenomena yang diselidiki (Nazir, 1998). 


\section{Macam dan sumber data}

Penelitian ini menggunakan data sekunder. Data yang diperlukan berupa data runtut waktu (time series) dan data silang tempat (cross-section), yaitu data luas lahan, jumlah petani mitra, benih, pupuk, dan beberapa pestisida dan data pendukung lainnya mengenai tembakau rajangan rakyat tipe Magelangan dari tahun 2005 sampai tahun 2009.

Data yang diambil terdiri dari beberapa lokasi dimana ;Tembakau rajangan rakyat tipe Magelangan pada tahun 2005-2009 ada 3 Kabupaten yaitu Kab. Boyolali, Magelang dan Semarang, yang terdiri dari 8 Kecamatan pada tahun 2005, 7 Kecamatan pada tahun 2006, 9 Kecamatan pada tahun 2007, 9 Kecamatan pada tahun 2008, dan 11 Kecamatan pada tahun 2009.

\section{Analisis Data}

\section{Model Analisis Regresi Berganda}

Untuk melihat pengaruh faktor-faktor produksi terhadap produksi tembakau rajangan rakyat tipe Magelangan menggunakan persamaan :

$$
\operatorname{Ln} Y=\operatorname{Ln} A+b 1 \operatorname{Ln} X 1+b 2 \operatorname{Ln} X 2+\quad+b 10 \operatorname{Ln} X 10+\ln D_{1}+\ln D_{2}+\ln D_{3}+\ln D_{4}+\mu
$$

dimana $\mathrm{Y}$ adalah produksi tembakau $(\mathrm{Kg})$, A adalah konstanta, $\mathrm{b}_{1}-\mathrm{b}_{14}$ adalah koefisien regresi variabel $\mathrm{X}, \mathrm{X} 1$ adalah luas lahan (Ha), X2adalah jumlah petani mitra (Orang), X3 adalah Benih (Gr), X4 adalah pupuk NPK BASAL/Fertila $(\mathrm{Kg}), \mathrm{X} 5$ adalah pupuk KNO3 $(\mathrm{Kg})$, X6 adalah pestisida Orthene/Roteen 75 SP $(\mathrm{Kg}), \mathrm{X} 7$ adalah pestisida pidomil $(\mathrm{Kg}), \mathrm{X} 8$ adalah pestisida Confidor $(\mathrm{Kg}), \mathrm{X}_{9}$ adalah pestisida Marcis (Lt), $X_{10}$ adalah Suckerisida Prime Plus 25 EC/Hylan (Lt), Di adalah Dummy Tahun (2005 sebagai Dummy Dasar) dimana D1 (2006 adalah 1, Tahun lainnya adalah 0), D2 (2007 adalah 1, Tahun lainnya adalah 0),D3 (2008 adalah 1, Tahun lainnya adalah 0), D4 (2009 adalah 1, Tahun lainnya adalah 0), $\mu$ adalah Kesalahan

Sedangkan untuk melihat pengaruh faktor-faktor produksi terhadap produksi dan produktivitas tembakau rajangan rakyat per hektar, yaitu dengan menggunakan persamaan :

$\operatorname{Ln} Y=\operatorname{Ln} A+b 1 \operatorname{LnZ1}+b 2 \operatorname{LnZ2}+\ldots+b 8 \operatorname{LnZ10}+\ln \mathrm{D}_{1}+\ln \mathrm{D}_{2}+\ln \mathrm{D}_{3}+\ln \mathrm{D}_{4}+\mu$

dimana:Y adalah produksi dan produktivitas tembakau $(\mathrm{Kg} / \mathrm{Ha}), \mathrm{A}$ adalah konstanta, $b_{1}-b_{14}$ adalah koefisien regresi Variabel $\mathrm{X}, \mathrm{Z1}$ adalah luas lahan tiap kecamatan (Ha), Z2 adalah petani (Orang), Z3 adalah benih(Gr), Z4 adalah pupuk NPK BASAL/Fertila $(\mathrm{Kg} / \mathrm{Ha})$, Z5 adalah pupuk KNO3 $(\mathrm{Kg} / \mathrm{Ha}), \mathrm{Z6}$ adalah Pestisida Orthene/Roteen $75 \mathrm{SP}(\mathrm{Kg} / \mathrm{Ha}), \mathrm{Z7}$ adalah Pestisida Ridomil $(\mathrm{Kg} / \mathrm{Ha}), \mathrm{Z8}$ adalah Pestisida Confidor $(\mathrm{Kg} / \mathrm{Ha}), \mathrm{Z}$ 9 adalah Pestisida Marcis

134 | Eko Sumartono, Analisis Produksi Tembakau Rajangan Tipe Magelang ... 
(Lt/Ha), $\mathrm{Z}_{10}$ adalah Suckerisida Prim Plus 25 EC/Hylan (Lt/Ha), Di adalah Dummy Tahun (2005 sebagai Dummy Dasar) dimanaD ${ }_{1}(2006$ adalah 1, Tahun lainnya adalah 0$), \mathrm{D}_{2}$ (2007 adalah 1 , Tahun lainnya adalah 0$), \mathrm{D}_{3}$ (2008 adalah 1 , Tahun lainnya adalah0), $\mathrm{D}_{4}$ (2009 adalah 1, Tahun lainnya adalah0), padalahKesalahan.

\section{Keterbatasan Penelitian}

Penelitian ini lebih difokuskan pada penelitian pendeskripsian analisis kuantitatif. Pada penelitian ini analisis kualitatif tidak disajikan, karena terdapat beberapa keterbatasan, antara lain:Adanya kesulitan dalam pengambilan data seperti data kualitas, karena keterbatasan data dilapangan.

\section{HASIL DAN PEMBAHASAN}

\section{Tingkat Penggunaan Input}

\section{Tembakau Rajangan Rakyat Tipe Magelangan}

Perkembangan tingkat penggunaan lahan, petani mitra, dan benih pada usahatani tembakau rajangan rakyat tipe Magelangan, dari tahun 2005 hingga 2009 dapat dilihat pada Tabel 1 berikut ini:

Tabel 1. Perkembangan Tingkat Penggunaan Luas Lahan dan Petani Mitra pada Usahatani Tembakau Rajangan Rakyat Tipe Magelangan, Tahun 2005-2009.

\begin{tabular}{|c|c|c|c|c|c|c|c|c|c|c|}
\hline \multirow[t]{2}{*}{ Tahun } & \multirow{2}{*}{$\begin{array}{l}\text { Luas } \\
\text { Lahan } \\
(\mathrm{Ha})\end{array}$} & \multirow[t]{2}{*}{$\%$} & \multicolumn{2}{|c|}{$\begin{array}{c}\text { Petani Mitra } \\
\text { (Orang) }\end{array}$} & \multicolumn{2}{|c|}{$\%$} & \multicolumn{2}{|c|}{$\begin{array}{c}\text { Benih } \\
(\mathrm{Kg})\end{array}$} & \multicolumn{2}{|c|}{$\%$} \\
\hline & & & LT & $\mathrm{Ha}$ & LT & $\mathrm{Ha}$ & LT & $\mathrm{Ha}$ & LT & $\mathrm{Ha}$ \\
\hline 2005 & 411 & 0 & 964 & 2,34 & 0 & 0 & 3.898 & 9,48 & 0 & 0 \\
\hline 2006 & 40 & (2) & 52 & 1,3 & (45) & (44) & 4.834 & 12,00 & 24 & 27 \\
\hline 2007 & 533 & 32 & 1.105 & 2,07 & 110 & 59 & 6.044 & 11,34 & 25 & (5) \\
\hline 2008 & 635 & 19 & 1.540 & 2,4 & 39 & 17 & 6.894 & 10,85 & 14 & (4) \\
\hline 2009 & 1.050 & 65 & 2.486 & 2,37 & 61 & (2) & 9.779 & 9,32 & 42 & (14) \\
\hline
\end{tabular}

Sumber: CV.MERABU, 2010

Penurunan petani karena kurangnya minat petani dalam bertani tembakau pada tahun 2005 ada indikator kegagalan dipenanaman maupun processing akibat curah hujan yang begitu tinggi sehingga menyebabkan penurunan keikutsertaan petani pada tahun 2006. Kurangnya minat petani ini disebabkan oleh petani mengalami kesulitan dalam melaksanakan usahatani tembakau, kepercayaan petani yang belum maksimal, masih banyaknya petani yang ingin menjual daun basah di beberapa tempat, struktur wilayah sekitar petani 
(keadaan wilayah) yang hampir tidak bisa mengolah menjadi tembakau kering dan ketakutan petani mengembalikan kredit yang diberikan oleh pihak CV. MERABU.

Pada tahun 2007, meningkatnya kepercayaan, minat petani bergabung terhadap CV. MERABU dan pola pikir masyarakat petani yang sudah mau berubah dan mengubah usaha tani dibidang tembakau. Penggunaan benih per luas tanam terus mengalami peningkatan, adanya peningkatan pemberian benih dari pihak CV. MERABU kepada petani mitra yang dikarenakan pada tahun 2006 proses pembuatan benih cadangan diperbanyak agar nantinya tidak terjadi kekurangan benih. Namun, pada aplikasinya penggunaan benih per hektar mengalami penurunan. Hal ini menunjukkan bahwa petani menambah luas lahan yang digunakan untuk usahatani, tanpa menambah penggunaan benih.

Tabel 2 menunjukkan bahwa pada seluruh luas tanam tingkat penggunaan pupuk NPK pada tahun 2006 mengalami penurunan sebesar 3\% dan peningkatan penggunaan pada tahun 2007 hingga 2009, yaitu 35\% pada tahun $2007,15 \%$ pada tahun 2008, dan $74 \%$ pada tahun 2009. Demikian pula dengan tingkat penggunaan pupuk KNO3 mengalami penurunan pada tahun 2006, yaitu sebesar $4 \%$ dan peningkatan pada tahun-tahun berikutnya, yaitu pada tahun 2007 mengalami peningkatan sebesar 34\%, pada tahun 2008 mengalami peningkatan sebesar 33\%, dan pada tahun 2009 mengalami peningkatan sebesar $69 \%$. Selanjutnya pada penggunaan per hektar, pupuk NPK pada tahun 2006 mengalami penurunan sebesar 1\% dan pada tahun 2008 sebesar $4 \%$, sedangkan peningkatan penggunaan terjadi pada tahun 2007 dan 2009, yaitu $2 \%$ pada tahun 2007 , dan $6 \%$ pada tahun 2009 . Sedangkan penggunaan pupuk KNO3 mengalami penurunan pada tahun 2006, yaitu sebesar $2 \%$ dan peningkatan pada tahun-tahun berikutnya, yaitu pada tahun 2007 mengalami peningkatan sebesar $2 \%$, pada tahun 2008 mengalami peningkatan sebesar $11 \%$, dan pada tahun 2009 mengalami peningkatan sebesar 2\%. Adanya penurunan pupuk yaitu sesuai dengan penurunan petani yang bergabung dalam kemitraan.

Tabel 2. Perkembangan Tingkat Penggunaan Pupuk pada Usahatani Tembakau Rajangan Rakyat Tipe Magelangan, Tahun 2005-2009

\begin{tabular}{cccccccccc}
\hline \multirow{2}{*}{ Tahun } & \multicolumn{3}{c}{$\begin{array}{c}\text { NPK } \\
(\mathrm{Kg})\end{array}$} & \multicolumn{3}{c}{$\begin{array}{c}\text { Kenaikan } \\
\%\end{array}$} & \multicolumn{2}{c}{$\begin{array}{c}\text { KNO3 } \\
(\mathrm{Kg})\end{array}$} & \multicolumn{2}{c}{$\begin{array}{c}\text { Kenaikan } \\
\%\end{array}$} \\
\cline { 2 - 10 } & LT & Ha & & LT & Ha & LT & Ha & LT & Ha \\
\hline 2005 & 167.418 & 407 & (Fertila) & 0 & 0 & 64.965 & 158 & 0 & 0 \\
2006 & 163.097 & 405 & (Basal) & $(3)$ & $(1)$ & 62.648 & 156 & $(4)$ & $(2)$ \\
2007 & 219.782 & 412 & (Basal) & 35 & 2 & 84.257 & 158 & 34 & 2 \\
2008 & 252.417 & 397 & (Basal) & 15 & $(4)$ & 111.957 & 176 & 33 & 11 \\
2009 & 440.404 & 420 & (Basal) & 74 & 6 & 188.953 & 180 & 69 & 2 \\
\hline
\end{tabular}

Sumber : CV. MERABU, 2010

136 | Eko Sumartono, Analisis Produksi Tembakau Rajangan Tipe Magelang ... 
Peningkatan dan penurunan penggunaan berbagai pestisida pada luas tanam usahatani tembakau Rajangan Rakyat Tipe Magelangan ini bisa disebabkan menurun dan meningkatnya hama tanaman yang menyerang tanaman tembakau di beberapa tempat, petani yang kurang mau mengaplikasikan pestisida, kurangnya pengetahuan petani dalam mengaplikasikan pestisida secara tepat dan keterlambatan penyuluhan oleh field force. Serangan HPT yang berbeda- beda begitu juga pengaruh dari faktor-faktor iklim yang menunjang peningkatan HPT. Perkembangan tingkat penggunaan pestisida pada usahatani tembakau rajangan rakyat tipe Magelangan dari tahun 2005 hingga 2009 dapat dilihat pada Tabel 3.

Tabel 3. Perkembangan Tingkat Penggunaan Pestisida pada Usahatani Tembakau Rajangan Rakyat Tipe Magelangan, Tahun 2005-2009.

\begin{tabular}{|c|c|c|c|c|c|c|c|}
\hline \multirow{2}{*}{\multicolumn{3}{|c|}{ Jenis Pestisida }} & \multicolumn{5}{|c|}{ Tahun } \\
\hline & & & 2005 & 2006 & 2007 & 2008 & 2009 \\
\hline \multirow{5}{*}{ Orthene/Roteen (kg) } & \multicolumn{2}{|c|}{ LT } & 0 & 286 & 184 & 248 & 419 \\
\hline & \multirow{2}{*}{\multicolumn{2}{|c|}{ На }} & 0 & 0,71 & 0,35 & 0,39 & 0,4 \\
\hline & & & (O) & $(\mathrm{O})$ & (R) & (R) & (R) \\
\hline & \multirow{2}{*}{$\%$} & LT & 0 & 0 & -36 & 35 & 69 \\
\hline & & $\mathrm{Ha}$ & 0 & 0 & -51 & 13 & 2 \\
\hline \multirow{4}{*}{ Ridomil Gold (kg) } & \multicolumn{2}{|c|}{ LT } & 748 & 793 & 1.030 & 944 & 1.587 \\
\hline & \multicolumn{2}{|c|}{$\mathrm{Ha}$} & 1,82 & 1,97 & 1,93 & 1,49 & 1,51 \\
\hline & & LT & 0 & 6 & 30 & -8 & 68 \\
\hline & & $\mathrm{Ha}$ & 0 & 8 & -2 & -23 & -2 \\
\hline \multirow{4}{*}{ Confidor (Kg) } & \multicolumn{2}{|c|}{$\begin{array}{l}\text { LT } \\
\end{array}$} & 367 & 367 & 496 & 619 & 973 \\
\hline & \multicolumn{2}{|c|}{$\mathrm{Ha}$} & 0,89 & 0,91 & 0,93 & 0,98 & 0,93 \\
\hline & & LT & 0 & 0 & 35 & 25 & 57 \\
\hline & & $\mathrm{Ha}$ & 0 & 2 & 2 & 5 & -5 \\
\hline \multirow{4}{*}{ Marcis 25 EC } & \multicolumn{2}{|c|}{$\begin{array}{l}\text { LT } \\
\end{array}$} & 466 & 327 & 430 & 490 & 902 \\
\hline & \multicolumn{2}{|c|}{$\mathrm{Ha}$} & 1,134 & 0,812 & 0,806 & 0,772 & 0,86 \\
\hline & & LT & 0 & -30 & 31 & 14 & 84 \\
\hline & & $\mathrm{Ha}$ & 0 & -8 & -1 & -4 & 11 \\
\hline \multirow{5}{*}{ Hylan-Prime Plus (lt) } & \multicolumn{2}{|c|}{ LT } & 1582 & 1602 & 2039 & 1872 & 3201 \\
\hline & \multirow{2}{*}{\multicolumn{2}{|c|}{ Ha }} & 3,848 & 3,976 & 3,826 & 2,947 & 3,05 \\
\hline & & & $(\mathrm{H})$ & $(\mathrm{H})$ & $(\mathrm{H})$ & $(\mathrm{P})$ & (P) \\
\hline & & LT & 0 & 1 & 27 & -8 & 71 \\
\hline & & $\mathrm{Ha}$ & 0 & 3 & -4 & -23 & 3 \\
\hline
\end{tabular}

Sumber :CV. MERABU, 2010 
ISSN -1412-8837

\section{Tingkat Produksi dan Produktivitas}

\section{Tembakau Rajangan Rakyat Tipe Magelangan}

Perkembangan tingkat produksi dan produktivitas pada usahatani tembakau rajangan rakyat tipe Magelangan, dari tahun 2005 hingga 2009 dapat dilihat pada Tabel 4 berikut ini:

Tabel 4 Perkembangan Tingkat Produksi dan Produktivitas pada Usahatani Tembakau Rajangan Rakyat Tipe Magelangan, Tahun 2005-2009.

\begin{tabular}{ccccr}
\hline Tahun & $\begin{array}{c}\text { Produksi } \\
(\mathrm{Kg})\end{array}$ & $\begin{array}{c}\text { Kenaikan } \\
\%\end{array}$ & $\begin{array}{c}\text { Produktivitas } \\
(\mathrm{Kg} / \mathrm{ha})\end{array}$ & $\begin{array}{c}\text { Kenaikan } \\
\%\end{array}$ \\
\hline 2005 & 441.586 & 0,000 & 9862,006 & 0,000 \\
2006 & 415.446 & $(5,920)$ & 6839,897 & $(30,644)$ \\
2007 & 610.759 & 47,013 & 9885,656 & 44,529 \\
2008 & 751.437 & 23,033 & 10510,619 & 6,322 \\
2009 & 1.277 .188 & 69,966 & 13064,322 & 24,296 \\
\hline
\end{tabular}

Sumber: CV. MERABU, 2010

Penurunan dan kenaikan produksi dan produktivitas pada usahatani tembakau rajangan rakyat tipe Magelangan disebabkan penurunan dan peningkatan keikutsertaan petani sehingga berpengaruh penurunan dan peningkatan luas lahan yang digunakan untuk usahatani tembakau rajangan rakyat tipe Magelangan. Penurunan dan peningkatan produksi dan produktivitas pada tembakau rajangan rakyat tipe Magelangan disebabkan proses kerja produksi tembakau rajangan tipe Magelangan setiap tahunnya dapat dipengaruhi cuaca yang tidak menentu sehingga berpengaruh pada proses produksi dan produktivitas setiap tahunnya. Selain itu juga, proses produksi tidak terlepas dari teknis budidaya beberapa petani yang masih beragam.

\section{Perbandingan Tingkat Produksi dan Produktivitas Tembakau}

Perbandingan tingkat produksi dan produktivitas tembakau yaitu untuk melihat perbedaan rata-rata produksi dan produktivitas antara tembakau rajangan rakyat tipe Magelangan dan tembakau rajangan rakyat tipe Muntilanan digunakan analisis uji-t dua sampel independen yang hasilnya tersaji pada Tabel 5 . 
Tabel 5. Hasil Analisis Komparasi Produksi dan Produktivitas Tembakau Rajangan Rakyat Tipe Magelangan

\begin{tabular}{llrcrr}
\hline No & $\begin{array}{c}\text { Variabel } \\
\text { Bebas }\end{array}$ & Rata-rata & $\begin{array}{c}\text { Perbedaan } \\
\text { rata-rata } \\
\text { bagian bawah }\end{array}$ & $\begin{array}{c}\text { Perbedaan } \\
\text { rata-rata } \\
\text { bagian atas }\end{array}$ & t-hitung \\
\hline $\begin{array}{l}\text { 1. } \\
\text { 2. Produksi }\end{array}$ & $\begin{array}{r}71.710,89 \\
\text { Produktivitas }\end{array}$ & $-7,51$ & $-99.457,00$ & $93.964,78$ & $6,386^{* * *}$ \\
\hline $\begin{array}{l}\text { Keterangan: } \\
* * * \\
\text { adalah signifikan pada taraf kepercayaan 99\% (a adalah } \\
\text { t-tabel adalah2,621 }\end{array}$ & $0,01)$ & $-0,163 \mathrm{~ns}$ \\
\hline
\end{tabular}

Hasil analisis perbedaan rata-rata produksi, diperoleh nilai t-hitung sebesar 6,389 > dibandingkan t-tabel 2,621 pada taraf kepercayaan 99\%, yang menunjukkan bahwa rata-rata produksi tembakau rajangan rakyat tipe Magelangan benar-benar berbeda. Karena t-hitung memiliki angka positif, maka produksi tembakau rajangan rakyat tipe Magelangan mempunyai rata-rata lebih besar. Perbedaan rata-rata produksi tembakau rajangan rakyat tipe Magelangan antara $49.457 \mathrm{~kg}$ sampai dengan $93.964,78 \mathrm{~kg}$, dengan perbedaan rata-rata adalah $71.710,89 \mathrm{~kg}$.

Selanjutnya hasil analisis perbedaan rata-rata produktivitas, diperoleh nilai t-hitung sebesar -0,163 $\leq$ dibandingkan t-tabel 2,621 pada taraf kepercayaan $99 \%$, yang menunjukkan bahwa rata-rata produktivitas tembakau rajangan rakyat tipe Magelangan sama. Jika dilihat dari angka negatif, menunjukkan bahwa produktivitas tembakau rajangan rakyat tipe Magelangan mempunyai rata-rata lebih kecil. Perbedaan rata-rata produktivitas tembakau rajangan rakyat tipe Magelangan berkisar antara 98,68 kg sampai dengan 83,65 kg, dengan perbedaan rata-rata adalah $7,51 \mathrm{~kg}$.

\section{Faktor-Faktor yang Mempengaruhi Produksi dan Produktivitas Tembakau.}

\section{Produksi Tembakau Rajangan Rakyat Tipe Magelangan}

Hasil analisis faktor-faktor produksi terhadap produksi tembakau rajangan rakyat tipe Magelangan dalam kemitraan CV. MERABU dengan menggunakan analisis regresi untuk melihat Koefisien Regresi $\left(\mathrm{Uji}^{2}{ }^{2}\right)$, Uji Simultan (Uji F), dan Uji Individual (Uji t) dapat dilihat pada tabel 6.

Hasil analisis regresi diperoleh nilai koefesien determinasi $\left(R^{2}\right)$ sebesar 0,996 . Hasil penelitian ini berarti bahwa secara simultan variabel bebas (independent) berpengaruh nyata terhadap variabel terikat (dependent) yaitu produksi tembakau rajangan rakyat tipe Magelangan sebesar 99,6\%. Sedangkan sisanya sebesar $0,4 \%$ dijelaskan oleh faktor-faktor lain yang tidak dimasukan dalam model persamaan regresi. Hasil analisis Uji F menunjukkan bahwa nilai F-hitung sebesar 484,739 lebih besar dari F-tabel pada taraf kepercayaan 99\% 
yaitu sebesar 2,767. Hal ini berarti bahwa variabel bebas secara bersama-sama berpengaruh nyata terhadap variabel terikat, yaitu produksi tembakau rajangan rakyat tipe Magelangan.

Tabel 6. Hasil Analisis Regresi Faktor-Faktor Produksi yang Mempengaruhi Produksi Tembakau Rajangan Rakyat Tipe Magelangan

\begin{tabular}{|c|c|c|c|}
\hline Variabel Bebas & $\begin{array}{c}\text { Koef. } \\
\text { Regresi }\end{array}$ & $\begin{array}{c}\text { Standar } \\
\text { error }\end{array}$ & t-hitung \\
\hline LnLuas Lahan $\left(\operatorname{LnX}_{1}\right)$ & 3,935 & 1,205 & $3,266^{* * *}$ \\
\hline LnJumlah Petani Mitra $\left(\operatorname{LnX}_{2}\right)$ & 0,151 & 0,096 & $1,573 \mathrm{~ns}$ \\
\hline LnBenih $\left(\operatorname{LnX}_{3}\right)$ & $-0,143$ & 0,207 & $-0,691 \mathrm{~ns}$ \\
\hline LnPupuk NPK Fertila/Basal (LnX $\left.{ }_{4}\right)$ & $-2,357$ & 0,872 & $-2,703 * *$ \\
\hline LnPupuk KNO3 $\left(\operatorname{LnX}_{5}\right)$ & $-0,514$ & 0,777 & $-0,662 n s$ \\
\hline LnPestisida Ortheen/Roteen 75 SP $\left(\mathrm{LnX}_{6}\right)$ & 0,135 & 0,039 & $3,469 * * *$ \\
\hline LnPestisida Ridomil $\left(\mathrm{LnX}_{7}\right)$ & 0,061 & 0,101 & $0,596 \mathrm{~ns}$ \\
\hline LnPestisida Confidor $\left(\mathrm{LnX}_{8}\right)$ & $-0,219$ & 0,298 & $-0,734 \mathrm{~ns}$ \\
\hline LnPestisida Marcis $\left(\operatorname{LnX}_{9}\right)$ & 0,097 & 0,163 & $0,592 \mathrm{~ns}$ \\
\hline LnSuckerisida Hylan/Prim Plus 25 EC (LnX 10$)$ & $-0,121$ & 0,209 & $-0,577 \mathrm{~ns}$ \\
\hline $2006\left(D_{1}\right)$ & $-1,101$ & 0,335 & $-3,288 * * *$ \\
\hline $2007\left(D_{2}\right)$ & $-0,837$ & 0,307 & $-2,726^{* *}$ \\
\hline $2008\left(D_{3}\right)$ & $-0,859$ & 0,319 & $-2,695^{* *}$ \\
\hline $2009\left(D_{4}\right)$ & $-0,749$ & 0,326 & $-2,300 * *$ \\
\hline
\end{tabular}

Konstanta $=25,079$

Standar Error regresi $\quad=6,793$

$\mathrm{R}^{2}=0,996$

F-hitung $=484,739$

F-tabel $=2,767$

t-tabel $=2,756(\alpha=1 \%)$, dan 2,045 ( $\alpha=5 \%)$

Sumber: Analisis Data Sekunder, 2010.

Keterangan: *** signifikan pada taraf kepercayaan 99\% (aadalah0,01)

** signifikan pada taraf kepercayaan 95\% (adalah0,05)

ns non signifikan

Pengaruh masing-masing variabel bebas secara individual terhadap variabel terikat digunakan uji individual (Uji t). Hasil analisis menunjukkan bahwa luas lahan, Pestisida Ortheen/Roteen 75 SP, dan Dummy 1 (tahun 2006) berpengaruh nyata terhadap produksi tembakau rajangan rakyat tipe Magelangan pada taraf kepercayaan 99\%, dimana nilai t-hitung luas lahan sebesar 3,266, pestisida Ortheen/Roteen 75 SP sebesar 3,469, dan Dummy 1 (tahun 2006) sebesar -3,288 lebih besar dibandingkan t-tabel pada taraf kepercayaan 99\% yaitu sebesar 2,756. Sedangkan Dummy 2 (tahun 2007), Dummy 3 (tahun 2008), dan Dummy 4 (tahun 2009) berpengaruh nyata terhadap produksi tembakau rajangan rakyat tipe Magelangan pada taraf kepercayaan 
95\%, dimana nilai t-hitung Dummy 2 (tahun 2007) sebesar -2,726, Dummy 3 (tahun 2008) sebesar -2,695, dan Dummy 4 (tahun 2009) sebesar -2,300 lebih besar dibandingkan t-tabel pada taraf kepercayaan 95\% yaitu sebesar 2,045.

Hasil analisis menunjukkan bahwa jumlah petani mitra, benih, Pupuk KNO3, Pestisida Ridomil, Pestisida Confidor, Pestisida Marcis, dan Suckerisida Prime Plus 25 EC/Hylan tidak berpengaruh nyata terhadap produksi tembakau rajangan rakyat tipe Magelangan baik pada taraf kepercayaan 99\%, 95\%, maupun $90 \%$.

Konstanta sebesar 25,079 menyatakan bahwa jika variabel bebas dianggap konstan, maka produksi tembakau rajangan rakyat tipe Magelangan akan meningkat sebesar 25,079 Kg.Koefisien regresi LnLuas Lahan $\left(\operatorname{Ln} X_{1}\right)$ sebesar 3,935 menyatakan setiap penambahan $1 \%$ luas lahan akan meningkatkan produksi tembakau rajangan rakyat tipe Magelangan sebesar 3,935\%. Koefisien regresi LnPupuk NPK $\left(\operatorname{Ln} X_{4}\right)$ sebesar $-2,357$ menyatakan setiap penambahan $1 \%$ pupuk NPK akan menurunkan produksi tembakau rajangan rakyat tipe Magelangan sebesar 2,357\%. Koefisien regresi LnPestisida Ortheen-Roteen $\left(\mathrm{LnX}_{6}\right)$ sebesar 0,135 menyatakan setiap penambahan 1\% NPK akan meningkatkan produksi produksi tembakau rajangan rakyat tipe Magelangan sebesar $0,135 \%$.

Koefisien regresi Dummy tahun $2006\left(D_{1}\right)$ sebesar -1,101 menyatakan bahwa tingkat produksi tembakau rajangan rakyat tipe Magelangan tahun 2006 lebih kecil 1,101 Kg jika dibandingkan dengan tahun 2005.. Koefisien regresi Dummy Tahun $2007\left(D_{2}\right)$ sebesar -0,837 menyatakan bahwa tingkat produksi tembakau rajangan rakyat tipe Magelangan tahun 2007 lebih kecil 0,837 Kg jika dibandingkan dengan tahun 2005 dengan adanya berbagai faktor-faktor produksi yang mempengaruhinya.Koefisien regresi Dummy Tahun $2008\left(\mathrm{D}_{3}\right)$ sebesar -0,859 menyatakan bahwa tingkat produksi tembakau rajangan rakyat tipe Magelangan tahun 2008 lebih kecil 0,859 Kg jika dibandingkan dengan tahun 2005 dengan adanya berbagai faktor-faktor produksi yang mempengaruhinya.. Koefisien regresi Dummy Tahun $2009\left(D_{4}\right)$ sebesar -0,749 menyatakan bahwa tingkat produksi tembakau rajangan rakyat tipe Magelangan tahun 2008 lebih kecil 0,749 Kg jika dibandingkan dengan tahun 2005 dengan adanya berbagai faktor-faktor produksi yang mempengaruhinya.

Variabel-variabel yang tidak berpengaruh nyata terhadap produksi tembakau rajangan rakyat tipe Magelangan, yaitu jumlah petani mitra, benih, Pupuk KNO3, Pestisida Ridomil, Pestisida Confidor, Pestisida Marcis, dan Suckerisida Prime Plus 25 EC/Hylan tidak meningkatkan produksi tembakau rajangan rakyat tipe Magelangan dengan penambahan 1\% dari setiap faktorfaktor produksi tersebut. Hasil analisis menunjukkan bahwa tidak terjadi gejala multikolinearitas atau kecil sekali pengaruh gejala multikolinearitas antar variabel independen. Sedangkan asumsi heteroskedastisitas dapat terpenuhi 
dengan melihat penyebaran residual adalah tidak teratur, dimana plot yang terpencar dan tidak membentuk pola tertentu pada pengujian Scater Plot.

\section{Analisis Produktivitas Tembakau Rajangan Rakyat Tipe Magelangan}

Hasil analisis faktor-faktor produksi terhadap produktivitas tembakau rajangan rakyat tipe Magelangan dengan menggunakan analisis regresi untuk melihat Koefisien Regresi (Uji R²), Uji Simultan (Uji F), dan Uji Individual (Uji t) dapat dilihat pada tabel 7, berikut :

Tabel 7. Hasil Analisis Regresi Faktor-Faktor Produksi yang Mempengaruhi Produktivitas Tembakau Rajangan Rakyat Tipe Magelangan.

\begin{tabular}{|c|c|c|c|}
\hline Variabel Bebas & $\begin{array}{c}\text { Koef. } \\
\text { Regresi }\end{array}$ & $\begin{array}{c}\text { Standar } \\
\text { error }\end{array}$ & t-hitung \\
\hline LnLuas Lahan (LnZ1) & $-0,002$ & 0,015 &,$- 136 \mathrm{~ns}$ \\
\hline LnJumlah Petani Mitra $\left(\mathrm{LnZ}_{2}\right)$ & 0,210 & 0,092 & $2,281^{* *}$ \\
\hline LnBenih $(\operatorname{LnZ})_{3}$ & $-0,463$ & 0,212 & $-2,184^{* *}$ \\
\hline LnPupuk NPK Fertila/Basal (LnZ 4$)$ & $-2,862$ & 0,818 & $-3,497 * * *$ \\
\hline LnPupuk KNO3 (LnZ $\left.{ }_{5}\right)$ & $-0,210$ & 0,752 &,$- 280 \mathrm{~ns}$ \\
\hline LnPestisida Ortheen/Roteen 75 SP (LnZ6) & 0,661 & 0,154 & $4,292^{* * *}$ \\
\hline LnPestisida Ridomil $\left(\mathrm{LnZ}_{7}\right)$ & 0,124 & 0,098 & $1,267 \mathrm{~ns}$ \\
\hline LnPestisida Confidor $\left(\mathrm{LnZ}_{8}\right)$ & $-0,006$ & 0,282 &,$- 022 \mathrm{~ns}$ \\
\hline LnPestisida Marcis (LnZ9) & 0,355 & 0,141 & $2,526^{* *}$ \\
\hline Ln Suckerisida Hylan/PrimePlus 25 EC (LnZ10) & $-0,234$ & 0,189 & $-1,235 \mathrm{~ns}$ \\
\hline $2006\left(D_{1}\right)$ & $-2,659$ & 0,626 & $-4,250 * * *$ \\
\hline $2007\left(\mathrm{D}_{2}\right)$ & $-2,070$ & 0,531 & $-3,899 * * *$ \\
\hline $2008\left(\mathrm{D}_{3}\right)$ & $-2,237$ & 0,567 & $-3,943^{* * *}$ \\
\hline $2009\left(\mathrm{D}_{4}\right)$ & $-2,176$ & 0,585 & $-3,719 * * *$ \\
\hline Konstanta & 29,401 & & \\
\hline $\mathrm{R}^{2}$ & 0,663 & & \\
\hline \multicolumn{4}{|l|}{ F-hitung $=484,739$} \\
\hline \multicolumn{4}{|l|}{ F-tabel $=2,767$} \\
\hline $\mathrm{t}$-tabel $=2,756(\alpha=1 \%)$, dan $2,045(\alpha=5 \%)$ & & & \\
\hline
\end{tabular}

Sumber: Analisis Data Sekunder, 2010.

Keterangan: $\quad * * *$ adalah signifikan pada taraf kepercayaan 99\% $(\alpha=0,01)$

** adalah signifikan pada taraf kepercayaan $95 \%(a=0,05)$

ns adalah non signifikan

Hasil analisis regresi diperoleh nilai koefesien determinasi $\left(\mathrm{R}^{2}\right)$ sebesar 0,663 . Hasil penelitian ini berarti bahwa secara simultan variabel bebas (independent) berpengaruh nyata terhadap variabel terikat (dependent) yaitu produktivitas tembakau rajangan rakyat tipe Magelangan sebesar 66,3\%. Sedangkan sisanya sebesar 33,7\% dijelaskan oleh faktor-faktor lain yang tidak dimasukan dalam model persamaan regresi.

142 | Eko Sumartono, Analisis Produksi Tembakau Rajangan Tipe Magelang ... 
Hasil analisis Uji F menunjukkan bahwa nilai F-hitung sebesar 4,067 lebih besar dari F-tabel pada taraf kepercayaan 99\% yaitu sebesar 2,767. Hal ini berarti bahwa variabel bebas, berpengaruh nyata terhadap variabel terikat, yaitu produtivitas tembakau rajangan rakyat tipe Magelangan.

Pengaruh masing-masing variabel bebas secara individual terhadap variabel terikat digunakan uji individual (Uji t). Hasil analisis menunjukkan bahwa Pupuk NPK Fertila/Basal, Pestisida Ortheen/Roteen 75 SP, Dummy 1 (tahun 2006), Dummy 2 (tahun 2007), Dummy 3 (tahun 2008), dan Dummy 4 (tahun 2009) berpengaruh nyata terhadap produkivitas tembakau rajangan rakyat tipe Magelangan pada taraf kepercayaan 99\%, dimana nilai t-hitung Pupuk NPK Fertila/Basal sebesar -3,497, Pestisida Ortheen/Roteen 75 SP sebesar 4,292, Dummy 1 (tahun 2006) sebesar -4,250, Dummy 2 (tahun 2007) sebesar -3,899, Dummy 3 (tahun 2008) sebesar -3,943, dan Dummy 4 (tahun 2009) sebesar -3,719 lebih besar dibandingkan t-tabel pada taraf kepercayaan 99\% yaitu sebesar 2,756. Sedangkan jumlah petani mitra, benih dan pestisida Marcis berpengaruh nyata terhadap produktivitas tembakau rajangan rakyat tipe Magelangan pada taraf kepercayaan 95\%, dimana t-hitung jumlah petani mitra sebesar 2,281 dan pestisida Marcis sebesar 2,526 lebih besar dibandingkan t-tabel pada taraf kepercayaan 95\% yaitu sebesar 2,045.

Selanjutnya, hasil analisis menunjukkan bahwa luas lahan, Pupuk KNO3, Pestisida Ridomil, Pestisida Confidor, Suckerisida Prime Plus 25 EC/Hylan tidak berpengaruh nyata terhadap produktivitas tembakau rajangan rakyat tipe Magelangan baik pada taraf kepercayaan 99\%, 95\%, maupun 90\%. Hal ini ditunjukkan dari hasil uji $\mathrm{t}$ masing-masing variabel memiliki nilai $\mathrm{t}$ hitung $\leq \mathrm{t}$-tabel atau $\mathrm{t}$-hitung $\geq$-t-tabel baik pada taraf kepercayaan 99\%, 95\%, maupun $90 \%$, yaitu luas lahan sebesar $-0,136$, Pupuk KNO3 sebesar $-0,280$, Pestisida Ridomil sebesar 1,267, Pestisida Confidor sebesar -0,022, dan Suckerisida Prime Plus 25 EC/Hylan sebesar -1,235.

Konstanta sebesar 29,401 menyatakan bahwa jika variabel bebas dianggap konstan, maka produktivitas tembakau rajangan rakyat tipe Magelangan akan meningkat sebesar 29,401 Kg.Koefisien regresi LnJumlah Petani Mitra $\left(\mathrm{LnZ}_{2}\right)$ sebesar 0,210 menyatakan setiap penambahan 1\% jumlah petani miktra akan menimgkatkan produktivitas tembakau rajangan rakyat tipe Magelangan sebesar 0,210\%. Koefisien regresi LnBenih $\left(\mathrm{LnZ}_{3}\right)$ sebesar $-0,463$ menyatakan setiap penambahan $1 \%$ benih akan menurunkan produktivitas tembakau rajangan rakyat tipe Magelangan sebesar 0,463\%. Koefisien regresi LnPupuk NPK Fertila/Basal ( $\left.\mathrm{LnZ}_{4}\right)$ sebesar -2,862 menyatakan setiap penambahan $1 \%$ pupuk NPK Fertila/Basal akan menurunkan produktivitas tembakau rajangan rakyat tipe Magelangan sebesar 2,862\%. Koefisien regresi LnPestisida Ortheen-Roteen (LnZ 6 ) sebesar 0,661 menyatakan setiap penambahan 1\% Pestisida Ortheen-Roteen akan meningkatkan produktivitas tembakau rajangan rakyat tipe Magelangan sebesar 0,661\%. Koefisien regresi 
LnPestisida Marcis ( $\mathrm{LnZ}_{9}$ ) sebesar 0,355 menyatakan setiap penambahan 1\% Pestisida Marcis akan meningkatkan produktivitas tembakau rajangan rakyat tipe Magelangan sebesar 0,355\%.

Koefisien regresi Dummy tahun $2006\left(D_{1}\right)$ sebesar -2,659 menyatakan bahwa tingkat produktivitas tembakau rajangan rakyat tipe Magelangan tahun 2006 lebih kecil 2,659 Kg jika dibandingkan dengan tahun 2005 dengan adanya berbagai faktor-faktor produksi yang mempengaruhinya.Koefisien regresi Dummy Tahun $2007 \quad\left(D_{2}\right)$ sebesar -2,070 menyatakan bahwa tingkat produktivitas tembakau rajangan rakyat tipe Magelangan tahun 2007 lebih kecil 2,070 Kg jika dibandingkan dengan tahun 2005 dengan adanya berbagai faktorfaktor produksi yang mempengaruhinya.Koefisien regresi Dummy Tahun 2008 $\left(D_{3}\right)$ sebesar -2,237 menyatakan bahwa tingkat produktivitas tembakau rajangan rakyat tipe Magelangan tahun 2008 lebih kecil 2,237 Kg jika dibandingkan dengan tahun 2005 dengan adanya berbagai faktor-faktor produksi yang mempengaruhinya. Koefisien regresi Dummy Tahun $2009\left(D_{4}\right)$ sebesar -2,176 menyatakan bahwa tingkat produktivitas tembakau rajangan rakyat tipe Magelangan tahun 2008 lebih kecil 2,176 Kg jika dibandingkan dengan tahun 2005 dengan adanya berbagai faktor-faktor produksi yang mempengaruhinya.

Variabel-variabel yang tidak berpengaruh nyata terhadap produktivitas tembakau rajangan rakyat tipe Magelangan yaitu luas lahan, Pupuk KNO3, Pestisida Ridomil, Pestisida Confidor, Suckerisida Prime Plus 25 EC/Hylan tidak meningkatkan produktivitas tembakau rajangan rakyat tipe Magelangan dalam kemitraan CV. MERABU dengan penambahan $1 \%$ dari setiap faktorfaktor produksi tersebut.

Hasil analisis menunjukkan bahwa tidak terjadi gejala multikolinearitas atau kecil sekali pengaruh gejala multikolinearitas antar variabel independen. Sedangkan asumsi heteroskedastisitas dapat terpenuhi dengan melihat penyebaran residual adalah tidak teratur, dimana plot yang terpencar dan tidak membentuk pola tertentu pada pengujian Scater Plot.

\section{SIMPULAN DAN SARAN}

\section{Simpulan}

1. Rata-rata tingkat penggunaan input, baik jenis tembakau rajangan rakyat tipe magelangan mengalami penurunan drastis dari tahun 2005 ke 2006. Selanjutnya tingkat penggunaan input mengalami kenaikan, walaupun masih ada beberapa input yang mengalami penurunan yang disebabkan adanya pengurangan dosis pemakaian input tersebut.

2. Tingkat produksi dan produktivitas, jenis tembakau rajangan rakyat tipe magelangan mengalami penurunan drastis dari tahun 2005 ke 2006 seiring dengan penurunan jumlah petani yang ikut bergabung. Tingkat produksi 
dan produktivitas mengalami kenaikan. Ada yang mengalami penurunan, hal ini disebabkan adanya penurunan penggunaan input. Selanjutnya ratarata produksi tembakau rajangan rakyat tipe magelangan tersebut menunjukkan rata-rata produksi lebih tinggi Sedangkan rata-rata produktivitas tembakau rajangan rakyat tipe magelangan tidak menunjukkan adanya peningkatan.

3. Faktor-faktor produksi mempunyai pengaruh terhadap produksi dan produktivitas pada jenis tembakau rajangan rakyat tipe Magelangan. Secara individual, pengaruh faktor-faktor produksi adalah:

a. Luas lahan, Pestisida Ortheen/Roteen 75 SP, Dummy 1 (tahun 2006), Dummy 2 (tahun 2007), Dummy 3 (tahun 2008), dan Dummy 4 (tahun 2009) berpengaruh nyata terhadap produksi tembakau rajangan rakyat tipe Magelangan.

b. Jumlah petani mitra, Pupuk NPK Fertila/Basal, Pestisida Ortheen/Roteen 75 SP, pestisida Marcis, Dummy 1 (tahun 2006), Dummy 2 (tahun 2007), Dummy 3 (tahun 2008), dan Dummy 4 (tahun 2009). berpengaruh nyata terhadap produktivitas tembakau rajangan rakyat tipe Magelangan.

\section{Saran}

Kedepan pengembangan peningkatan produksi tembakau rajangan rakyat tipe Magelangan terus dilakukan sejalan dengan melakukan peningkatan produktivitas dan CV. MERABU dapat membina lebih baik petani tembakau rajangan rakyat tipe Magelangan dan potensi terbesar produksi masih dapat dikembangkan. Penelitian lebih spesifik terhadap tanaman tembakau itu sendiri dan pengaruhnya terhadap iklim yang tidak menentu.

CATATAN: Artikel ini merupakan bagian dari thesis dengan judul yang dipecah menjadi dua bagian type produk dari Eko Sumartono.

\section{DAFTAR PUSTAKA}

Akehurst, B.C. 1981. Tobacco 2nd ed. Longman. London.

Allard. 1960. Principles of plant breeding. John Wiley and Sons, Inc. New York London - Sydney.

Balitas.2000. Pencapaian Produksi dalam Budidaya Tembakau. Balitas. Malang. Ghozali, I. 2002. Aplikasi Analisis Multivariate Dengan Program SPSS. Penerbit Badan Penerbit Universitas Diponegoro. Semarang.

Hartono, S. 2008. Pemrakiraan Agribisnis. Hand Out. Universitas Gadjah Mada, Yogyakarta.

Heady, O.E and J.L.Dillon. 1965. Agriculture Production. The Lowa State University Press. 
Keputusan Menteri Pertanian no. : 60/kpts/kb.510/2/98 tanggal 19 Februari 1998 tentang Pembinaan dan Pengendalian Pengembangan Perkebunan Pola Perusahaan Inti Rakyat. Deptan, Jakarta.

Keputusan Menteri Pertanian Nomor: 940/Kpts/OT.210/10/97 Tentang Pedoman Kemitraan Usaha Pertanian.

Kuswanto.S. 2003. Prosiding Lokakarya Pengembangan Agribisnis Tembakau, Puslitbangbun Bogor.

Nazir, Moh. 1998. Metode Penelitian. Ghalia Indonesia. Jakarta.

Salvatore, D. 2005 Managerial Economics. Ekonomi Manajerial dalam Perekonomian Global. Salemba Empat Jakarta.

Santosa, P.B dan Ashari. 2005. Analisis Statistik dengan Microsoft Excel dan SPSS.Penerbit Andi, Yogyakarta.

Situs Hijau - Media Pertanian Online Anda, 2008. Pola Kemitraan Alternatif AndalanSektorAgribisnis. http://www.situshijau.co.id. 29 Mei 2010.

Soekartawi. 1994. Teori Ekonomi Produksi dengan Pokok Bahasan Analisis Fungsi Cobb-Douglas. Raja Grafindo Persada, Jakarta.

146 | Eko Sumartono, Analisis Produksi Tembakau Rajangan Tipe Magelang ... 